\title{
Gomphocalyx and Phylohydrax (Rubiaceae): sister taxa excluded from Spermacoceae s.s., featuring a remarkable case of convergent evolution*
}

\author{
Steven Dessein 1 , Lennart Andersson ${ }^{2}$, Koen Geuten ${ }^{1}$, Erik Smets ${ }^{1}$ \& Elmar Robbrecht ${ }^{3}$ \\ ${ }^{1}$ Laboratory of Plant Systematics, K. U. Leuven, Kasteelpark Arenberg 31, B-3001 Leuven, Belgium. steven \\ .dessein@bio.kuleuven.ac.be (author for correspondence) \\ ${ }^{2}$ Botanical Institute, Göteborg University, P.O. Box 461, SE 40530 Göteborg, Sweden. lennart.andersson@ \\ botany.gu.se \\ ${ }^{3}$ National Botanic Garden of Belgium, Domein van Bouchout, B-1860 Meise, Belgium.elmar.robbrecht@br. \\ fgov.be
}

\begin{abstract}
The genera Gomphocalyx and Phylohydrax (Rubiaceae) have been invariably placed in the tribe Spermacoceae s.s. based on the uni-ovulate ovary locules and pluri-aperturate pollen grains. Sequence data from the rps 16 intron and the $r b c L$ gene here presented exclude Gomphocalyx and Phylohydrax from Spermacoceae s.s. The two genera are closely related and their nearest relatives are found among members of the former tribe Hedyotideae. This position may be surprising at first, because the growth form of Phylohydrax is similar to some observed in Spermacoceae s.s. A detailed survey of morphological and anatomical characters shows, however, that the character states of the two genera are largely consistent with the here-proposed position in Hedyotideae. The creeping growth form, the uni-ovulate ovaries and the pluri-colporate pollen grains of Gomphocalyx and Phylohydrax are the result of convergence between this pair of genera and Spermacoceae s.s. The taxonomic position of Lathraeocarpa, sometimes considered closely related to Gomphocalyx, is also discussed.
\end{abstract}

KEYWORDS: convergent evolution, Gomphocalyx, Hydrophylax, Phylohydrax, Rubiaceae, Spermacoceae.

\section{INTRODUCTION}

The present paper deals mainly with two genera of the family Rubiaceae, Gomphocalyx Baker and Phylohydrax Puff. These taxa have been placed in Spermacoceae as traditionally delimited (e.g., Schumann, 1891; Robbrecht, 1988). Although Bremer (1996) and Bremer \& Manen (2000) argue that the tribe Spermacoceae should be emended to include most of the tribes Hedyotideae, Triainolepideae, Knoxieae and Manettieae, the Spermacoceae as traditionally conceived are still monophyletic (Andersson \& Rova, 1999; Terrell \& Wunderlin, 2002). In what follows, we will refer to it as Spermacoceae s.s. Morphologically, this clade is mainly characterized by uni-ovulate ovary locules and pluriaperturate pollen grains.

Gomphocalyx herniarioides Baker is a procumbent to decumbent herb (Figs. 1b, 3) endemic to Madagascar. In the protologue of the genus, Baker (1887) considered it close to Hydrophylax L. f. and Ernodea Sw., two members of Spermacoceae s.s. This position seems supported by the pluri-zonocolporate pollen grains and uni-ovulate locules of Gomphocalyx. Capuron (1973), however, supposed a relationship with the monogeneric tribe
Lathraeocarpeae, and Piesschaert (2001) even proposed merging Lathraeocarpa Bremek. with Gomphocalyx. Indeed, the two taxa are somewhat similar by having one ascending ovule per locule, rather undifferentiated plurizonocolporate pollen, and indehiscent fruits. Furthermore, Gomphocalyx and Lathraeocarpa share the peculiar character of having a calyx with eight lobes, while the corolla is 4-lobed.

Phylohydrax was established by Puff (1986) to accommodate one African and one Madagascan species of the genus Hydrophylax (placed in Spermacoceae s.s. by Robbrecht, 1988). The two species of this genus are pioneers of maritime dune vegetation, and show a differentiation into long creeping shoots and short flowering shoots (Figs. 1c, 2). Phylohydrax madagascariensis (Roem. \& Schult.) Puff is endemic to the eastern coast of Madagascar (but was recently also introduced in Tanzania), and P. carnosa (Hochst.) Puff is restricted to the east coast of continental Africa. The position of the genus in Spermacoceae s.s. has never been questioned (Puff, 1986). This is not surprising, since the species have uni-ovulate ovary locules and pluri-zonocolporate pollen grains. Moreover, a number of species from Spermacoceae s.s. have growth forms similar to the ones

*This article is dedicated to our good friend, colleague, and co-author, Lennart Andersson, who died unexpectedly while this paper was in press. 


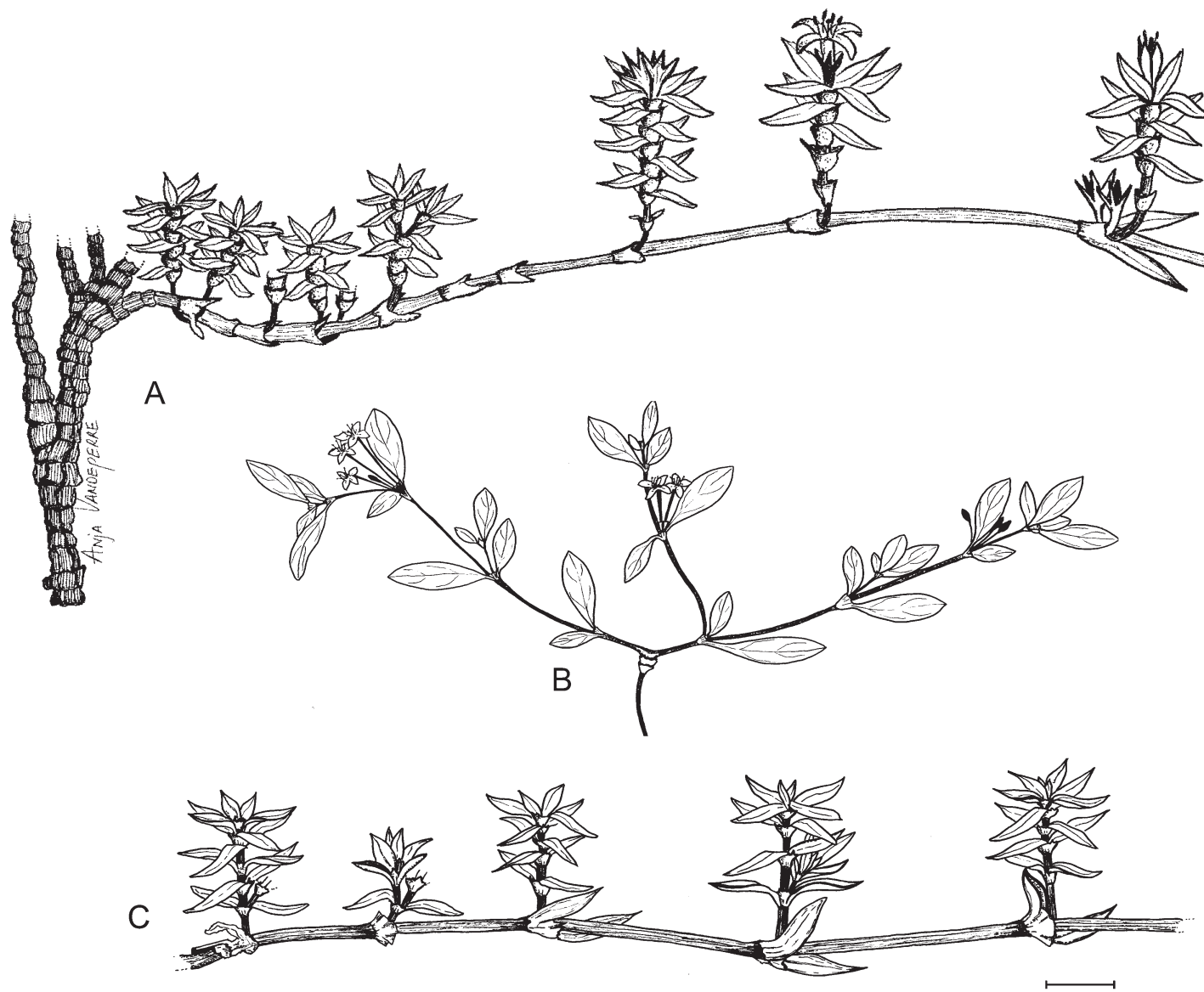

Fig. 1. Growth form. A, Hydrophylax maritima (Cooray 69011707R, Sri Lanka, BR); B, Gomphocalyx herniarioides (De Block \& al. 569, Madagascar, BR); C, Phylohydrax madagascariensis (De Block \& al. 640, Madagascar, BR). Scale bar = $1 \mathrm{~cm}$.

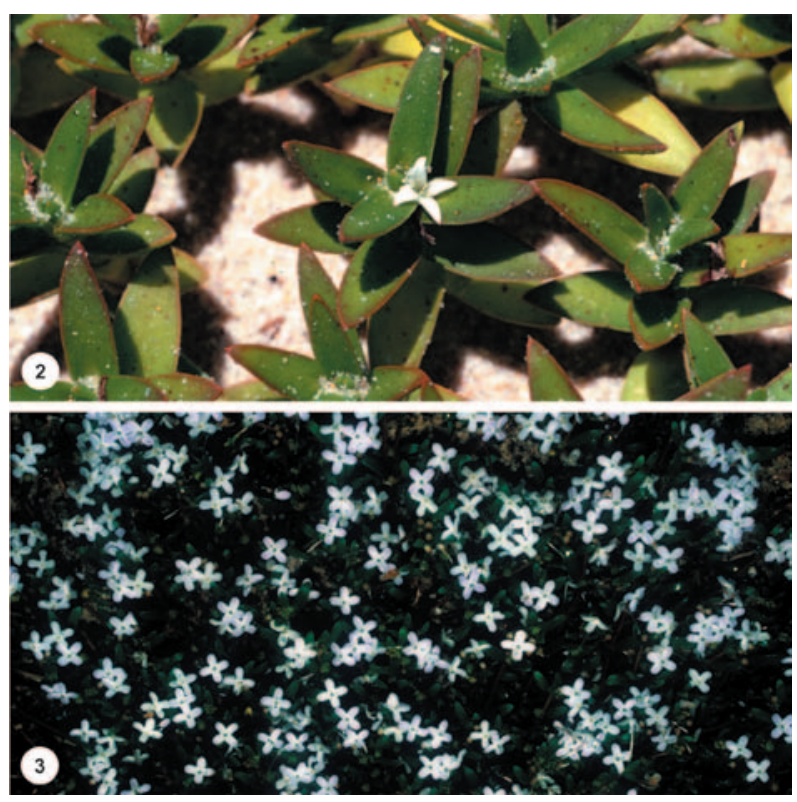

Figs. 2-3. Photographs of Phylohydrax madagascariensis (2) and Gomphocalyx herniarioides (3). Photos by Steven Dessein and Petra De Block, respectively. observed in Phylohydrax. In particular, the growth form of Hydrophylax maritima L. f. is very similar (Fig. 1a), being the main reason why the species of Phylohydrax were once placed in that genus.

We included Gomphocalyx and Phylohydrax in a phylogenetic study of Spermacoceae based on DNA sequence variation. Rather to our surprise, it turned out that these two are sister taxa, and that they do not belong to Spermacoceae s.s. but instead fall among taxa from the former tribe Hedyotideae. The present study presents this molecular evidence and identifies morphological and anatomical features consistent with (1) their exclusion from Spermacoceae s.s. and (2) their new position among members of the former tribe Hedyotideae. Therefore, a comparative morphological and anatomical study of the poorly known Gomphocalyx herniarioides is presented. The taxonomic position of Lathraeocarpa, a Madagascan genus sometimes linked with Gomphocalyx, is also discussed. 


\section{MATERIALS AND METHODS}

Morphological investigations. - The morphological study is based on herbarium material from BR, K, $\mathrm{MO}$, and P. Phylohydrax madagascariensis and Gomphocalyx herniarioides were also studied in the field, and pickled material collected by Petra De Block was available to investigate leaf, ovary, and seed anatomy.

Methods follow normal practice of herbarium taxonomy (De Vogel, 1987). The distribution map was produced using iMap (Schols \& al., 2001); the specimens used are listed in Appendix 1. Pollen data are based on observations of acetolysed pollen grains, which were obtained following Reitsma's "wetting agent" method (1969) as outlined by Dessein \& al. (2002).

Anatomical sections were made from tissues embedded in 2-hydroxyethyl methacrylate (GMA). The material was first dehydrated by putting the samples in increasing ethanol concentration ( 2 hours $70 \%, 2$ hours $96 \%, 2$ hours $100 \%$ ). They were then transferred to the infiltration medium for 36 hours ( $100 \mathrm{ml}$ Technovit 7100 resin and 1 gr of Hardener, i.e., dibenzoyl peroxide). Finally, the tissues were placed in the molds and covered with the embedding solution (15 parts of infiltrating solution and 1 part of Hardener II, dimethyl sulfoxide).

Molecular methods. - Some rps16 intron sequences were obtained following the protocols described by Andersson \& Rova (1999). Others, produced at the Laboratory of Plant Systematics (K. U. Leuven), were obtained by the methods described below.

Total genomic DNA was extracted from leaf tissues of fresh, silica-dried or herbarium material. The isolation method followed the procedure as described by Geuten $\&$ al. (2004). The buffer consisted of 2\% CTAB, 2\% PVP-40, 2\% 2-mercaptoethanol $(\mathrm{pH} 9.5)$ and $4 \mathrm{mM}$ DIECA and $5 \mathrm{mM}$ ascorbic acid (Chase \& Hills, 1991). The extract was washed two times with ethanol $76 \%$ $\mathrm{NH}_{4}$ Ac. The rps 16 intron was amplified on a DNA Thermal cycler 480 or a GeneAmp 9700 (Applied Biosystems) thermal cycler using the rps F and rpsR2 primers described by Oxelman \& al. (1997). Taq polymerase used was supplied by Amersham Pharmacia Biotech or Fermentas. Invariably, $25 \mu \mathrm{l} \mathrm{PCR}$ reactions were run. Denaturation $\left(95^{\circ} \mathrm{C}, 2 \mathrm{~min}\right)$ was followed by 25-35 cycles of denaturation at $95^{\circ} \mathrm{C}(30 \mathrm{sec})$, primer annealing at $55-57^{\circ} \mathrm{C}(1 \mathrm{~min})$, and extension at $72^{\circ} \mathrm{C}(2$ min), ending with a final extension for $7 \mathrm{~min}$ at $72^{\circ} \mathrm{C}$. The amplification products were purified with Qiaquick (Qiagen) spin columns according to the manufacturer's instructions.

Dideoxy sequencing was conducted using the BigDye dye terminator cycle sequencing protocol (from Applied Biosystems) with addition of 5\% DMSO. The sequencing products were purified by an isopropanol precipitation (modified from protocol supplied by Applied Biosystems). The sequencing reactions were analyzed with an ABI PRISMTM 310 Genetic Analyzer. Sequences were verified and edited with the Staden Package.

GenBank accession numbers with voucher specimen and country of origin are given in Appendix 2. Sequences were aligned manually. Some regions of the rps 16 intron could not be aligned with confidence and were deleted from the final matrices. Indel coding for the rps 16-intron followed the criteria as described by Andersson \& Rova (1999).

\section{RESULTS}

Molecular evidence. - While analyzing ITS sequences of members of Spermacoceae s.s., we noticed that Gomphocalyx and Phylohydrax were nested among the outgroup taxa. Since only a few ITS sequences are available for the subfamily Rubioideae, it was impossible to find the closest relatives of the two genera based on these data alone. For this reason, rps 16 intron sequences were determined as well. These sequences were then combined with sequences available in GenBank. A few preliminary analyses with representatives of the major groups of Rubiaceae included showed that the closest relatives of the two genera were amongst former Hedyotideae. The final matrix then also contains numerous taxa from Spermacoceae alliance with a few taxa from the Psychotria L. alliance as outgroup (see Appendix 2). The aligned rps 16 intron matrix had 897 characters, 470 of which were constant, 178 variable but uninformative, and 249 informative. The cladistic analysis was done with PAUP* 4.0b10 (Swofford, 2002). A jackknife analysis of 1000 replicates was performed with the following parameters: $37 \%$ of characters deleted in each replicate; each replicate with 20 random addition sequence replicates; 5 trees saved in each replicate, and TBR branch swapping. A combined $r b c L$ and $r p s 16$ intron matrix was also analyzed. Only those taxa for which the two genes were available were retained in this second matrix, except for Gomphocalyx for which only the rps 16 intron sequence is available. The same search procedure as described for the rps 16 intron matrix was performed. Of the 2315 characters, 1615 were constant, 329 were variable but uninformative, and 371 were informative.

The tree (Fig. 4) derived from the rps16 intron sequences is largely in agreement with the cladogram published by Andersson \& Rova (1999). The emended tribe Knoxieae sensu Andersson \& Rova (including the Hedyotideae-Pentas group, Triainolepideae, and the gen- 
era Carphalea and Otiophora) forms the sister group of a clade that comprises Anthospermeae, Danaideae, the Hedyotideae-Hedyotis group, Manettieae, Paederieae, Rubieae, and Spermacoceae s.s.

The tree based on $r p s 16$ intron and $r b c L$ sequences (Fig. 5) is similar to the tree published by Bremer and Manen (2000), which was based on $r p s 16, r b c L$ and $a t p B-r b c L$ spacer data. In contrast to the latter study, however, Paederieae, Theligoneae, Anthospermeae, Rubieae, and Argostemmateae do not form a monophyletic group but appear unresolved as four groups that form a polytomy together with Spermacoceae sensu Bremer \& Manen. Apparently, the support for this group in the study of Bremer \& Manen (2000) is mainly based on the $a t p B-r b c L$ spacer data.

The main difference between the two trees here presented lies in the position of emended Knoxieae. In the combined analysis, this group no longer takes a basal position, but is the sister group of a clade comprising most genera of the former tribe Hedyotideae and Spermacoceae s.s. However, the basal position in the rps 16 analysis had only ambiguous support.

In the two analyses, most genera traditionally included in Spermacoceae form a monophyletic group within a clade that comprises members of the former tribe Hedyotideae. This is not the case for Phylohydrax and Gomphocalyx. They come out as sister taxa in a strongly supported clade containing inter alia Conostomium (Stapf) Cufod. and Amphiasma Bremek., two genera endemic to mainland Africa, formerly placed in Hedyotideae and considered closely related to Oldenlandia L. (Bremekamp, 1952; Verdcourt, 1976).

Morphology and anatomy of Gomphocalyx. - Whereas Phylohydrax was rather well documented by Puff (1986), not a single study has been devoted to the morphology and anatomy of Gomphocalyx. Therefore, detailed morphological and anatomical data are here provided for Gomphocalyx with reference to character states observed in the Spermacoceae s.s. and Hedyotideae. These data will then be confronted with the molecular evidence. Morphological data of the main taxa under discussion are summarized in Table 1.

Growth form. - Gomphocalyx herniarioides is a prostrate or decumbent herb, sometimes forming dense mats (Figs. 1b, 3). The green or reddish-brown stems radiate from the somewhat woody base and are up to 50 $\mathrm{cm}$ long (usually shorter). They are much branched, round in cross-section, and finely ribbed. Stems are usually glabrous, although just below the stipule sheath the ribs may be scabrid. The primary root is well-developed and often somewhat woody. The species has always been described as annual, but as many specimens studied have a somewhat woody base and taproot, it is probably perennial.

This type of growth form is frequently observed among members of Hedyotideae and is not uncommon in Spermacoceae s.s. either.

Leaves and stipules. - Leaves are decussate,

Table 1. Character states as observed in Gomphocalyx, Lathraeocarpa, Phylohydrax, Hydrophylax, and Spermacoceae s.s. for some selected characters.

\begin{tabular}{|c|c|c|c|c|c|}
\hline Characters & Gomphocalyx & Lathraeocarpa & Phylohydrax & Hydrophylax & Spermacoceae s.s. \\
\hline Growth form & $\begin{array}{l}\text { procumbent or } \\
\text { decumbent (?) } \\
\text { perennial herbs }\end{array}$ & subshrubs & $\begin{array}{l}\text { perennial herbs with } \\
\text { differentiation into } \\
\text { creeping long shoots } \\
\text { and short erect shoots }\end{array}$ & $\begin{array}{l}\text { perennial herbs with } \\
\text { differentiation into } \\
\text { creeping long shoots } \\
\text { and short erect shoots }\end{array}$ & $\begin{array}{l}\text { procumbent, decumbent or erect; } \\
\text { mostly annual or perennial herbs, but } \\
\text { also shrubs and lianas }\end{array}$ \\
\hline Leaf & amphistomatic & unknown & amphistomatic & hypostomatic & hypostomatic and amphistomatic \\
\hline Leaf mesophyll & differentiated & unknown & palisades only & differentiated & differentiated \\
\hline Heterostyly & present & present & present & absent & absent in most taxa, sometimes present \\
\hline Calyx tube & reduced & reduced & well-developed & reduced & reduced \\
\hline $\begin{array}{l}\text { Number of calyx } \\
\text { lobes }\end{array}$ & 8 & 8 & $\begin{array}{l}4, \text { reduced to colleter- } \\
\text { tipped outgrowths }\end{array}$ & 4 & $0,2,(3-) 4,8$ \\
\hline $\begin{array}{l}\text { Corolla tube } \\
\text { Ovule position }\end{array}$ & $\begin{array}{l}\text { narrowly cylindrical } \\
\text { attached near base } \\
\text { of septum }\end{array}$ & $\begin{array}{l} \pm \text { cylindrical } \\
\text { attached near base } \\
\text { of septum }\end{array}$ & $\begin{array}{l}\text { funnel-shaped } \\
\text { attached near base } \\
\text { of septum }\end{array}$ & $\begin{array}{l}\text { funnel-shaped } \\
\text { attached just below } \\
\text { middle of septum }\end{array}$ & $\begin{array}{l}\text { (narrowly) cylindrical, funnel-shaped } \\
\text { attached near or below middle of } \\
\text { septum, rarely near base }\end{array}$ \\
\hline Nectary disk & 2-lobed & cylindrical & cylindrical & 2-lobed & 2-lobed or cylindrical \\
\hline Stigma & 2-armed & 4-armed & 2-armed & subcapitate & often subcapitate, rarely 2 -armed \\
\hline Fruit type & dry and indehiscent & drupes & $\begin{array}{l}\text { dry and } \\
\text { indehiscent }\end{array}$ & $\begin{array}{l}\text { dry and } \\
\text { indehiscent }\end{array}$ & $\begin{array}{l}\text { often capsules or schizocarps, some- } \\
\text { times berries or drupes, rarely dry } \\
\text { and indehiscent }\end{array}$ \\
\hline Seed & $\begin{array}{l}\text { obovoid, ellipsoid or } \\
\text { pyriform without } \\
\text { ventral groove }\end{array}$ & unknown & $\begin{array}{l}\text { ellipsoid without } \\
\text { ventral groove }\end{array}$ & $\begin{array}{l}\text { ellipsoid with } \\
\text { ventral groove }\end{array}$ & $\begin{array}{l}\text { variably shaped, ventral groove } \\
\text { present, though sometimes wide } \\
\text { and obscure, absence of groove uncer- } \\
\text { tain in Schwendenera }\end{array}$ \\
\hline Pollen type & pluri-zonocolporate & $\begin{array}{l}\text { pluri- } \\
\text { zonocolporate }\end{array}$ & $\begin{array}{l}\text { pluri- } \\
\text { zonocolporate }\end{array}$ & $\begin{array}{l}\text { pluri- } \\
\text { zonocolporate }\end{array}$ & $\begin{array}{l}\text { pluri-zonocolporate, pluri-zonopo(ro)- } \\
\text { rate, pluri-pantopo(ro)rate, rarely } \\
\text { 3-colporate }\end{array}$ \\
\hline Pollen sexine & $\begin{array}{l}\text { (micro-)reticulate } \\
\text { with granules }\end{array}$ & $\begin{array}{l}\text { (micro-)reticulate } \\
\text { with granules }\end{array}$ & $\begin{array}{l}\text { (micro-)reticulate } \\
\text { with granules }\end{array}$ & $\begin{array}{l}\text { perforate with } \\
\text { microspines }\end{array}$ & $\begin{array}{l}\text { mostly perforate, (micro-)reticulate } \\
\text { or psilate with granules or microspines }\end{array}$ \\
\hline
\end{tabular}




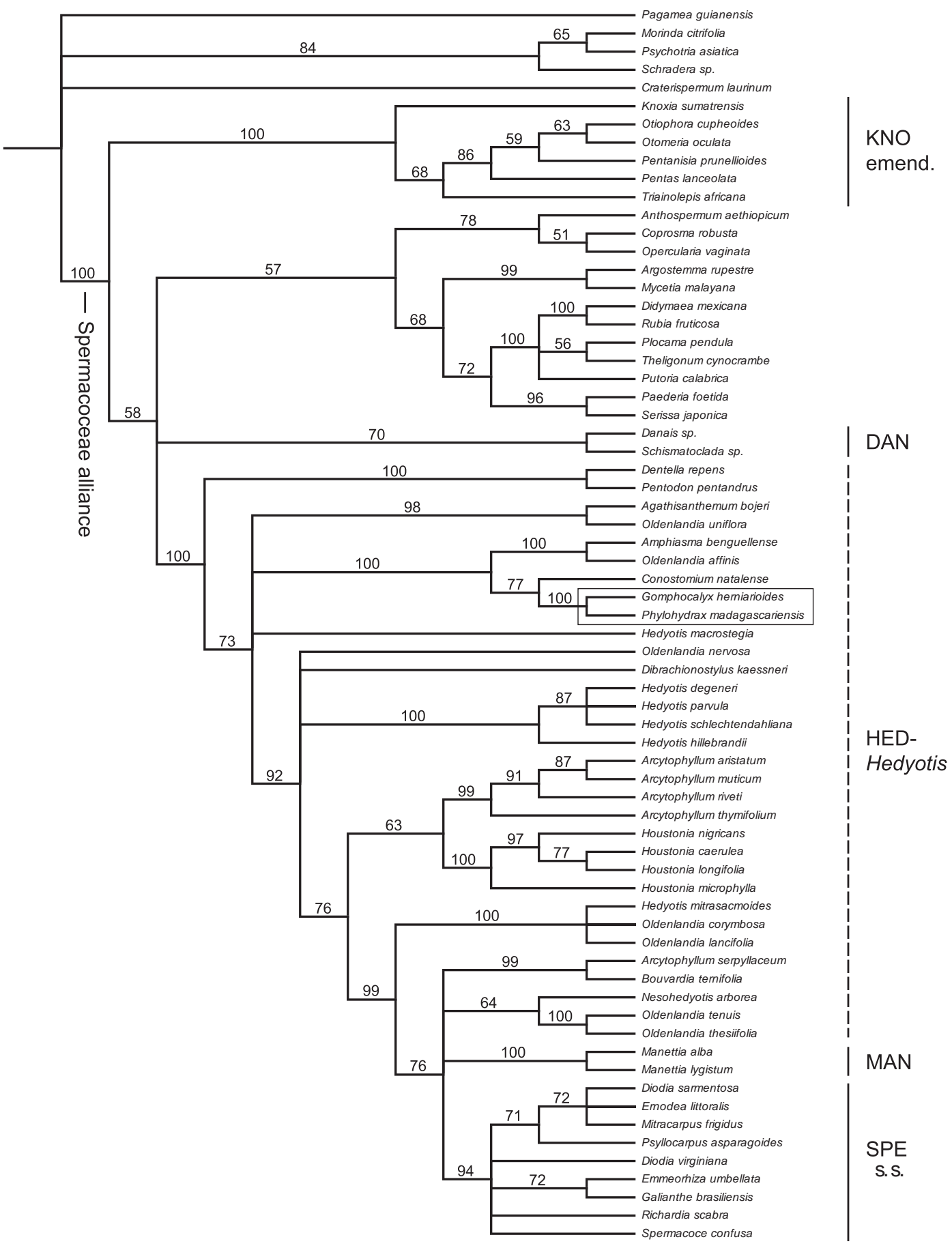

Fig. 4. Phylogeny of Spermacoceae alliance estimated on basis of rps16 intron sequences. Numbers above branches are jackknife support values. DAN = Danaideae; HED-Hedyotis = part of former Hedyotideae including Hedyotis; MAN = Manettieae; SPE = Spermacoceae; KNO emend. = emended Knoxieae sensu Andersson \& Rova.

sessile or rarely short-petiolate, and connate with the stipule base forming a sheath around the stem as observed within most members of the Spermacoceae sensu Bremer \& Manen. Leaf-blades are elliptic to narrowly elliptic, sometimes slightly ovate or obovate, rarely almost linear. They are mostly dark-green, turning yellowish-green when dried. They are $0.4-2.7 \mathrm{~cm}$ long and $0.1-0.8 \mathrm{~cm}$ wide, glabrous above and below or sparsely beset with scabrid hairs above. In most specimens, the leaves are distinctly anisophyllous (Fig. 1b). 


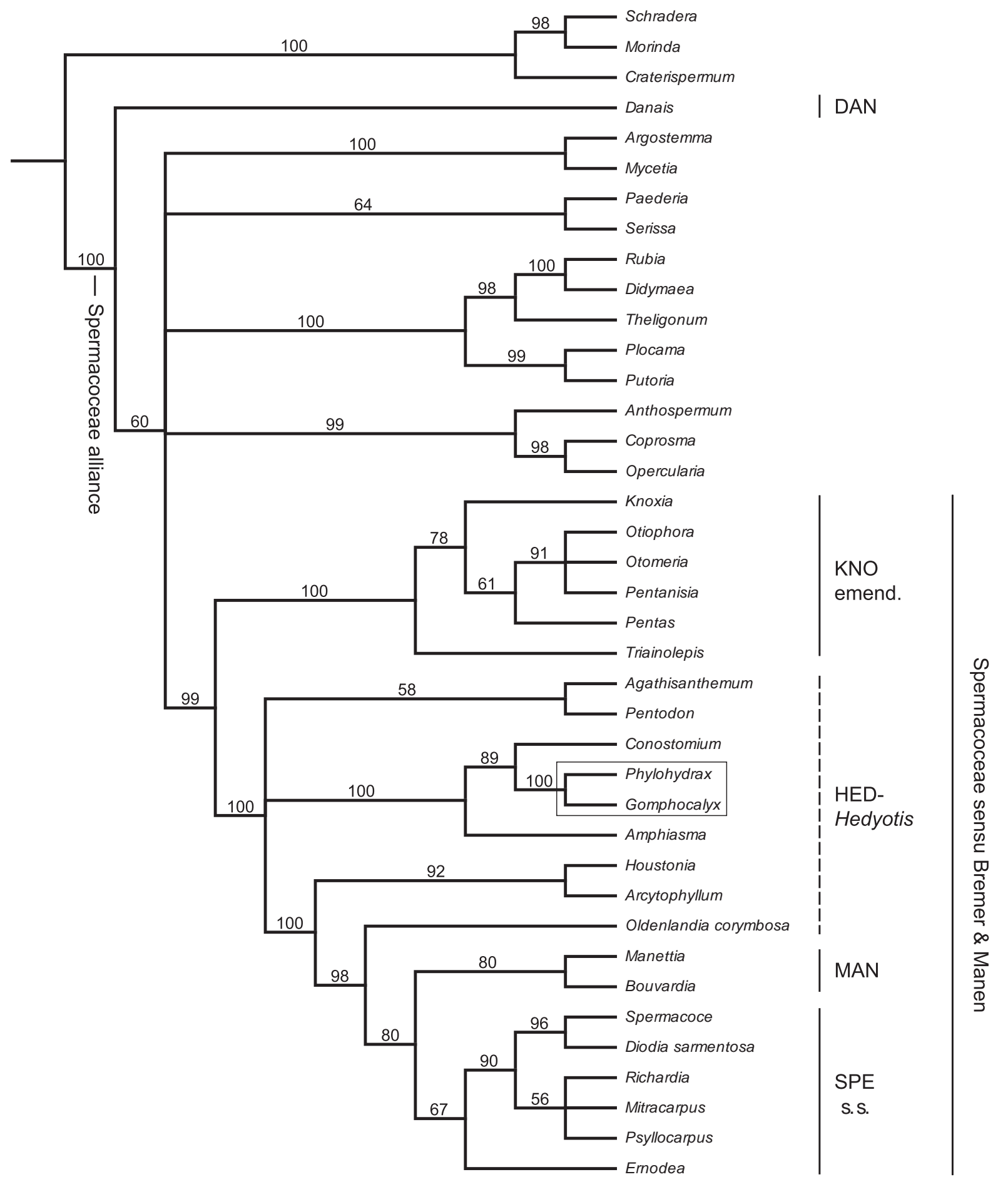

Fig. 5. Phylogeny of Spermacoceae alliance estimated on basis of $r p s 16$ intron and $r b c L$ data. Numbers above branches are jackknife support values. Abbreviations as in Fig. 4.

The margins are flat and minutely scabrate (often hardly visible on older leaves). The leaf apex is (broadly) acute to almost obtuse or slightly cuspidate; the base is variable, often gradually narrowed, sometimes attenuate, rounded or acute. The main vein is not very prominent and has up to 5 glabrous secondary veins on each side. The stipules are almost truncate. The stipule sheath is cup-shaped, 0.5-2 mm long, almost glabrous, and papery when dried. The stipule margin is irregular, sometimes crowned with a few short fimbriae, $0.2-1 \mathrm{~mm}$ long and 

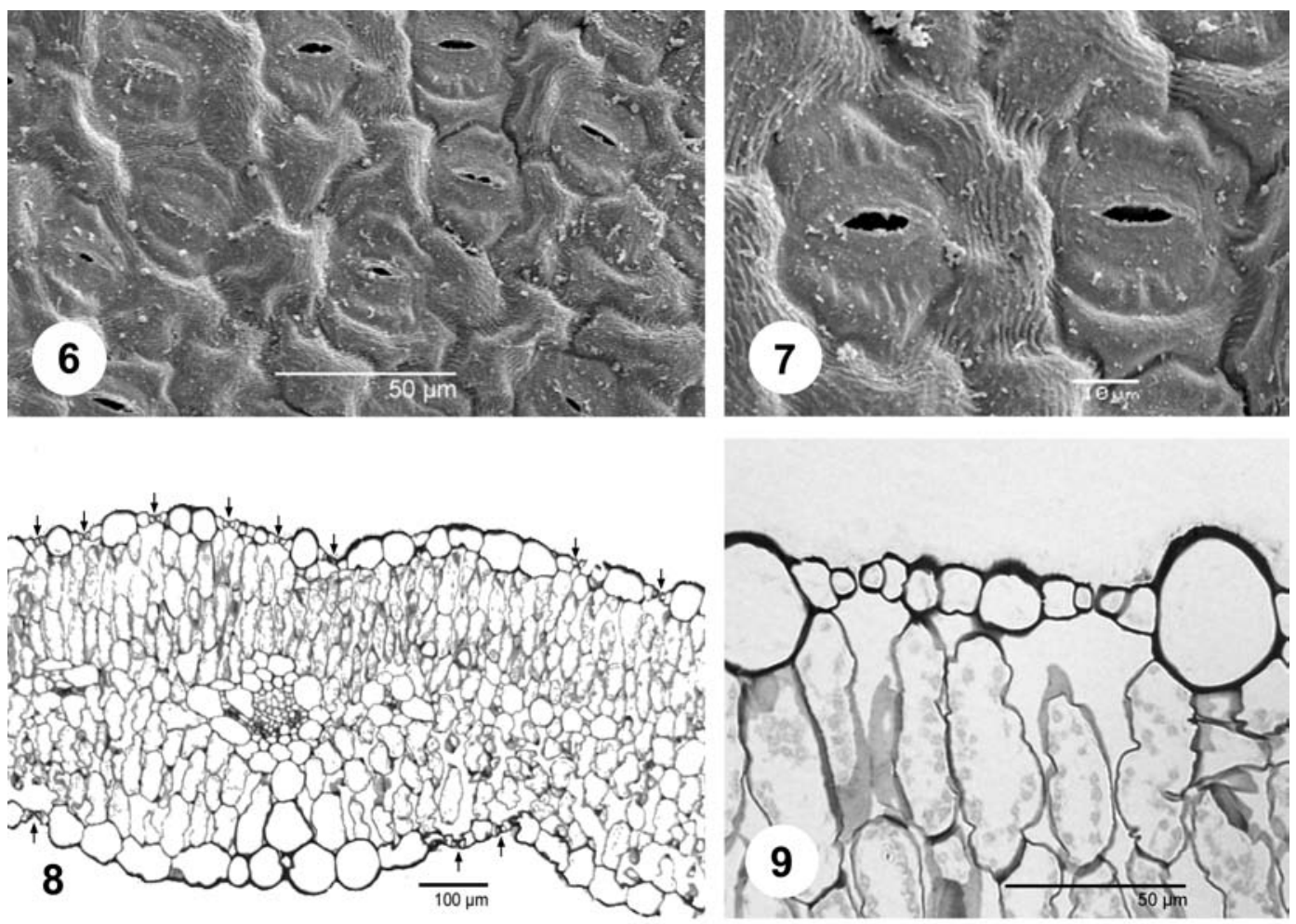

Figs. 6-9. Leaf morphology and anatomy of Gomphocalyx herniarioides. 6, detail of upper surface of leaf blade showing stomata; 7, detail of two stomata; 8, LM photo of cross-section through leaf with stomata (arrows); 9, LM photo of cross-section through leaf showing two neighboring stomata. All from De Block \& al. 569, Madagascar (BR).

colleter-tipped.

Leaf anatomy. - The somewhat fleshy leaves have a rather large-celled epidermis and a mesophyll made of 2-3 layers of palisade parenchyma and several layers of loosely arranged spongy cells (Fig. 8). Raphidecontaining idioblasts are present, preferentially in between the spongy and palisade layer. Tanniniferous idioblasts are absent. The vascular bundles lack obvious bundle sheaths and are inconspicuous, with the thicker median bundle comprising a few xylem and phloem cells only (Fig. 8).

Stomata are paracytic (Figs. 6, 7, 9), as often observed in Rubiaceae (see also Dessein \& al., 2001). The leaves are clearly amphistomatic, with a higher density of stomata on the upper surface (Fig. 8). Amphistomatic leaves are considered uncommon in Rubiaceae. It has been observed, however, in several Spermacoce species (Holm, 1907; Dessein, 2003), in Houstonia caerulea L., and in Phylohydrax.

Inflorescence. - The inflorescences of Gomphocalyx are few- to many-flowered with all the axes short, resulting in a dense cluster of flowers (Fig. 10). The cluster is ca. $0.3-0.5 \mathrm{~cm}$ wide in fruiting stage. The bracts are stipuliform, membranous and bear colleter-tipped setae, which rarely exceed $1 \mathrm{~mm}$. The inflorescences are initially terminal, but already during anthesis they are pushed aside by a developing shoot in one of the axils, which lengthens the stem. Consequently, the inflorescences appear axillary. These so-called pseudo-axillary inflorescences are frequently observed in Spermacoceae s.s. but are also found in Hedyotideae.

Flowers. - Gomphocalyx has heterostylous, 4merous flowers (not 5-merous as stated in the protologue of the genus). The calyx tube is reduced to a rim, or cupshaped and then up to ca. $0.4 \mathrm{~mm}$ high. It is glabrous or ciliate, with 1 or 2 colleters on the inside between the calyx lobes (Fig. 13). The number of lobes is basically 8 (fruits with 7 lobes are sometimes observed), and the lobes are (broadly) triangular and $0.2-0.5(-1.5) \mathrm{mm}$ long (Figs. 12-13). They are usually glabrous or ciliate, rarely densely hairy. The 8-partite condition of the calyx is probably derived from an originally 4-merous calyx, since larger and smaller lobes alternate with each other. Four interstitial lobes, becoming as large as the four true lobes, seem to have developed in Gomphocalyx.

The corolla tube is narrowly cylindrical and very variable in length, ranging from 4 up to $16 \mathrm{~mm}$. Most corolla tubes are 8-12 $\mathrm{mm}$ long, and $0.3-1 \mathrm{~mm}$ wide, the narrowest point being at or just above the base and the broadest point at the mouth. The corolla is glabrous throughout, or scabrate on the nerves outside and sparsely or more densely pubescent with short hairs inside (Fig. 

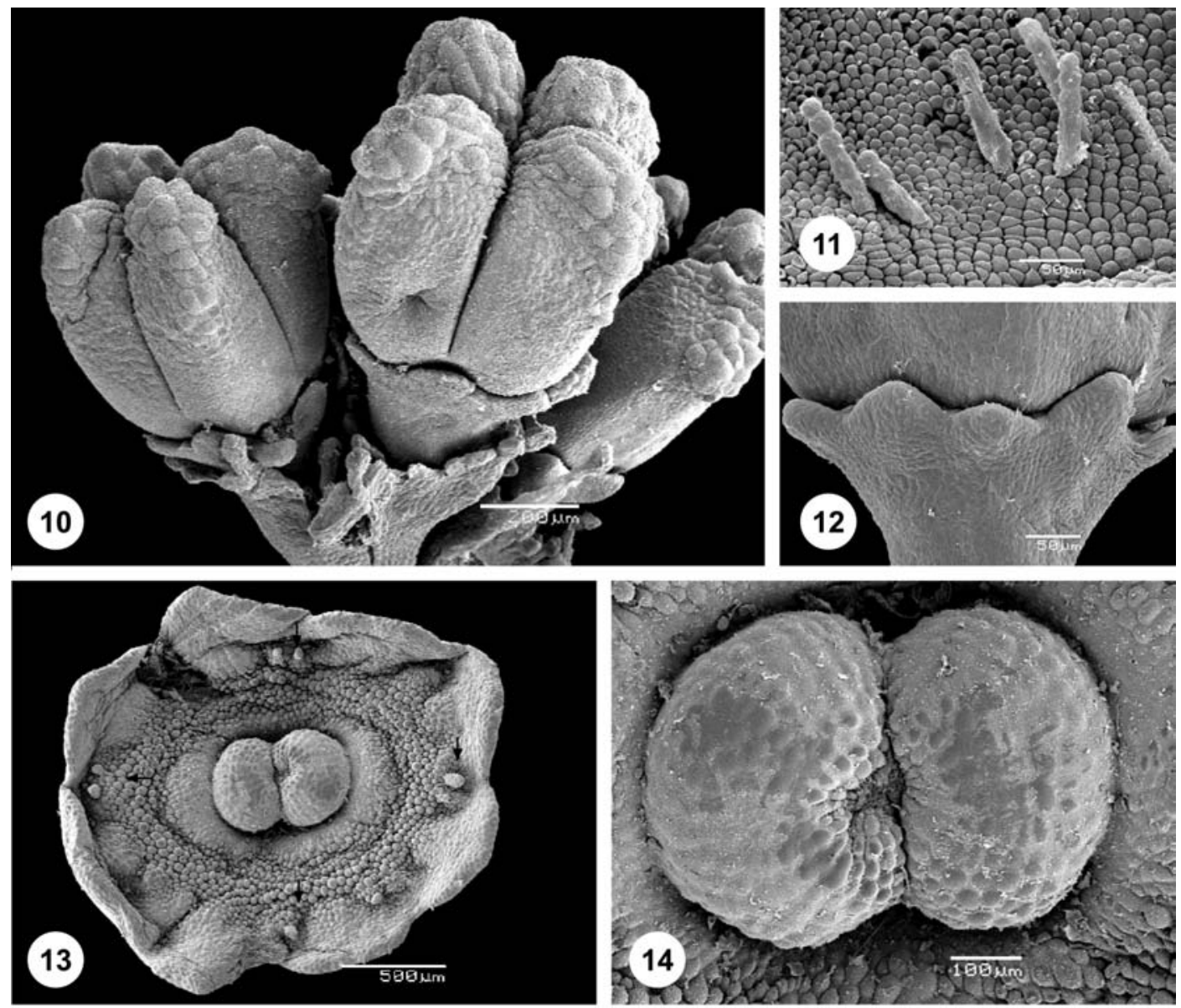

Figs. 10-14. Flower morphology of Gomphocalyx herniarioides. 10, flower buds: note the thickening of the distal part of corolla lobes; 11, inner surface of upper part of corolla; 12, detail of calyx morphology showing five of the eight minute calyx lobes: note the alternation of larger lobes with smaller 'interstitial' ones; 13, top view of ovary showing minute calyx lobes, colleters between the lobes, and nectary disc; 14, detail of bilobed nectary disc. All from De Block \& al. 569, Madagascar (BR).

11). The corolla lobes are elliptic to narrowly triangular, 2-5 $\mathrm{mm}$ long, and glabrous except for broad thick hairs at the tips outside (sometimes obscure) and a few hairs at the base inside. As the corolla tube, they are white or pale pink with a red streak at the base of each lobe.

The anthers are dorsifixed, with the filament attached near the base. They are elliptic to narrowly elliptic in outline, $0.6-1.2 \mathrm{~mm}$ long and open with longitudinal slits. In the longistylous form only the upper parts of the anthers are exserted. In brevistylous flowers the whole anthers are exserted for $0.5-1.5 \mathrm{~mm}$. The anthers appear white, yellow-green or brown (colour presumably correlated with the maturity of the pollen grains). The filaments are glabrous and white or pale purple.

The ovary is 2-locular (Fig. 15; sometimes one of the locules is aborted in fruit), obovoid to obconic, usually glabrous and (yellow) green. In young ovaries, the vascular bundles can be observed through the exocarp; on dried material they sometimes appear as ribs. Each ovary locule has one ovule (Figs. 15-16). The placenta is inserted at the base of the septum. Neither the ovule, nor the placenta show any kind of specialized outgrowth. The white style is included in the brevistylous form and exserted for ca. $1.5-2(-3) \mathrm{mm}$ in the longistylous form. In the longistylous morph, the stigma has two somewhat spreading papillose to shortly hairy lobes up to $1 \mathrm{~mm}$ long. In the brevistylous morph, the stigma lobes are connivent and sometimes somewhat longer. The nectary disc is found on top of the ovary, surrounding the base of the style. It is clearly bilobed, sunken into the ovary tissue at the early stages, but the central part is distinctly raised at later ones (Figs. 13, 14).

All of the flower characters observed in Gomphocalyx, except the uni-ovulate locules, are also observed among members of Spermacoceae s.s. and Hedyotideae. Uni-ovulate locules have never been reported from the latter group.

Pollen. - The pollen grains are 8-10-zono- 

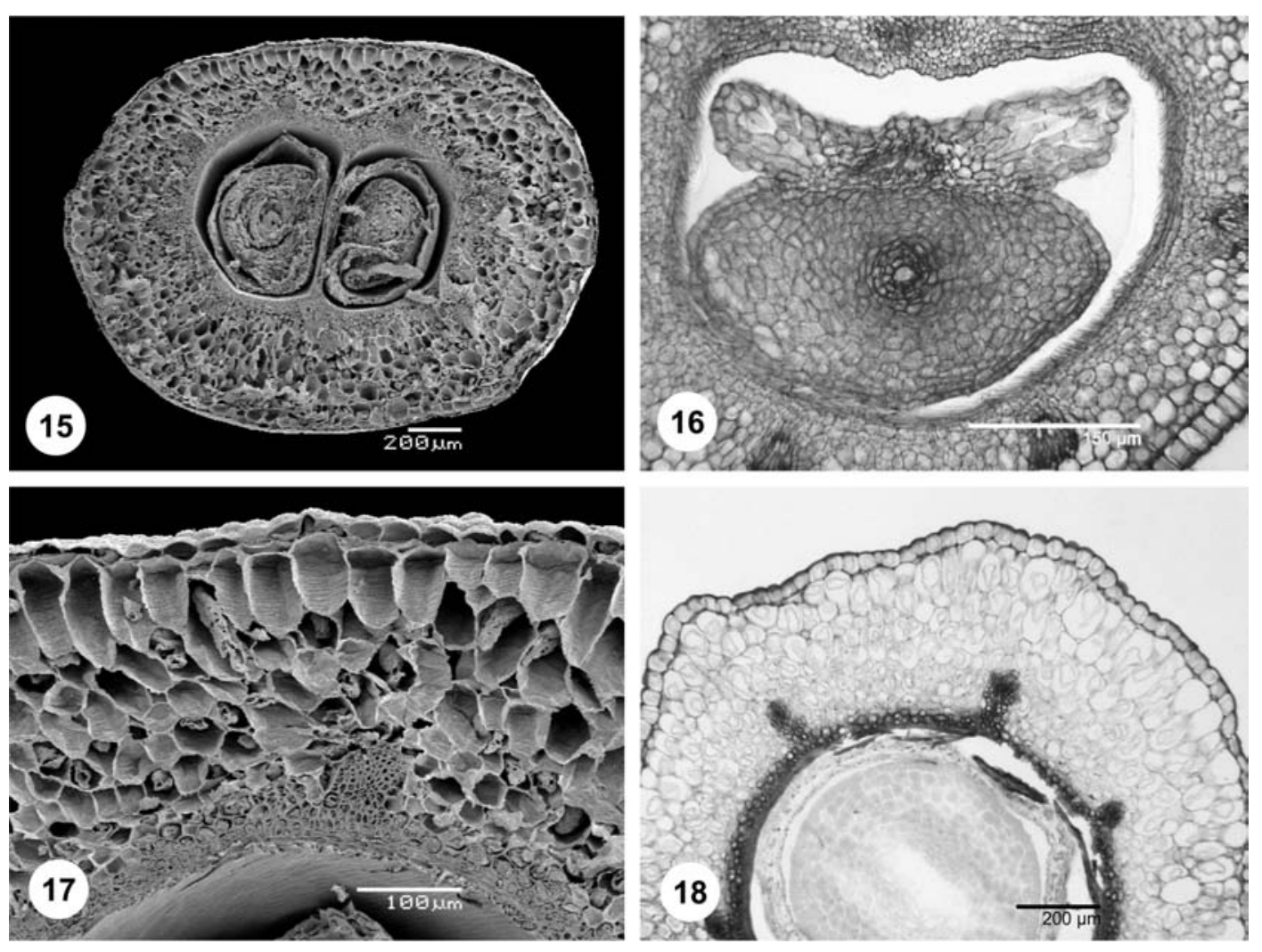

Figs. 15-18. Ovary and fruit wall of Gomphocalyx herniarioides. 15, transverse section through ovary/young fruit showing relatively thick wall; 16, LM photo of young locule in cross-section: notice the placenta and the developing ovule; 17 , detail of ovary wall; 18, LM photo of cross-section through young fruit. All from De Block \& al. 569, Madagascar (BR).

colporate, suboblate with an equatorial diameter of 45-55 $\mu \mathrm{m}$. The ectocolpi are short; the endoaperture is an endocingulum. The tectum is (micro-)reticulate, evenly covered with granules (Figs. 19-22). The inner nexine surface is granular. This pollen type is clearly more common in Spermacoceae s.s. than in Hedyotideae, in which 3-colporate pollen grains predominate (cf. Dessein \& al., 2000; Huysmans \& al. 2003).

Fruits. - The fruits are obconical (Fig. 23), often abruptly narrowed towards the base, $1.75-2.25 \times 1.25-2$ $\mathrm{mm}$ (including the beak), indehiscent, and crowned by the minute calyx lobes. Towards the lower part of the fruit, ribs are often distinctly visible. The fruit is comprised of three distinct layers: a one-layered exocarp, a thick and rather undifferentiated mesocarp and a thin but sclerenchymatous endocarp (Figs. 17, 18). The vascular bundles are initiated in the mesocarp (Fig. 16), but after outgrowth of the ovary into a fruit, they are positioned tight to the endocarp (Fig. 18).

Indehiscent fruits are rarely observed in both Spermacoceae s.s. and Hedyotideae, but are present in Phylohydrax (Fig. 26). A well-developed beak (outgrowth of the endocarp) is characteristic for many genera of Hedyotideae.

Seeds. - Seeds are obovoid to ellipsoid or somewhat pyriform, $1-1.5 \times 0.5-0.8 \mathrm{~mm}$, white. A ventral groove is absent. The seed-coat is parenchymatous without thickenings and somewhat reticulate in surface view (Figs. 24, 25). This seed type is not found in Spermacoceae s.s. nor in Hedyotideae, but is present in Phylohydrax (Figs. 27, 28). Seeds of Spermacoceae s.s. invariably have a more or less distinct ventral groove, while in Hedyotideae the seeds are much smaller and angular.

Distribution and habitat. - Gomphocalyx is mainly collected from sandy soils (one collection mentions limestone) in thorn forests, dunes and beaches up to $850 \mathrm{~m}$ high. Most collections come from two areas in the Western and Central part of Madagascar (Fig. 29): Majunga (Northwest Madagascar) and the area between Tulear (Southwest Madagascar) and Isalo (Central Madagascar). Only one collection comes from Ambovombe on the southern tip of Madagascar. The occurrence of the species in this part of the island needs confirmation through additional collections. As the species is widespread, it is not endangered. 



Figs. 19-22. Pollen morphology of Gomphocalyx herniarioides. 19, polar view of 10-zonocolporate pollen grain; 20, detail of apocolpium showing (micro-)reticulate tectum covered with small granules; 21, equatorial view of pollen grain; 22, detail of mesocolpium and colpi. All from De Block \& al. 569, Madagascar (BR).

\section{DISCUSSION}

The molecular results are surprising in two ways. First, a close relationship between Gomphocalyx and Phylohydrax has rarely been proposed in the literature. Second, their position in the vicinity of Amphiasma and Conostomium away from Spermacoceae s.S., seems at first sight in conflict with morphological and anatomical data. In the following paragraphs, we identify characters that do in fact indicate (1) a close relationship between Phylohydrax and Gomphocalyx and (2) their new position amidst former Hedyotideae genera. We also discuss the synonymy between Lathraeocarpa and Gomphocalyx as proposed by Piesschaert (2001).

Close relationship between Phylohydrax and Gomphocalyx. - Several morphological characters support a close relationship between the two genera, consistent with molecular data. In our opinion, the most conspicuous and essential similarities lie in flower, seed, and pollen characters. In both genera the ovary has two carpels with a single ovule per locule, with the micropyle pointing downwards. The placenta is attached near the base of the septum and there are no outgrowths associated with the placenta or ovule. Flower morphology is rather different in the two species: funnel-shaped in Phylohydrax, narrowly cylindrical in Gomphocalyx. In both the calyx lobes are small: eight minute calyx lobes in Gomphocalyx and a lacerate calyx vaguely showing two longer and two shorter lobes in Phylohydrax. Complete heterostyly is present in both genera, and the style ends in two papillose or shortly hairy stigmatic lobes. In both genera seeds are round in cross-section (there is no kind of ventral groove); the seed-coat is only weakly coloured, and the exotesta is parenchymatous and obscurely reticulate. Pollen grains are basically identical in the two genera, ca. 45-60 $\mu \mathrm{m}$ in diameter [Puff (1986) gives $\mathrm{E}=30-40 \mu \mathrm{m}$ for Phylohydrax pollen grains, but this is contradicted by our observations], with 8-12 short colpi situated at the equator [8-10 colpi in Gomphocalyx and 10-12 colpi in Phylohydrax], and a (micro-)reticulate tectum evenly covered with granules. Other similarities are the amphistomatic leaves, the papery stipular sheath with very short appendages only, and the dry indehiscent fruits.

Certainly, none of the enumerated characters represent synapomorphies for the two genera and only a few of them are useful at a rank higher than the species level. We will feed these doubts by listing the differences 

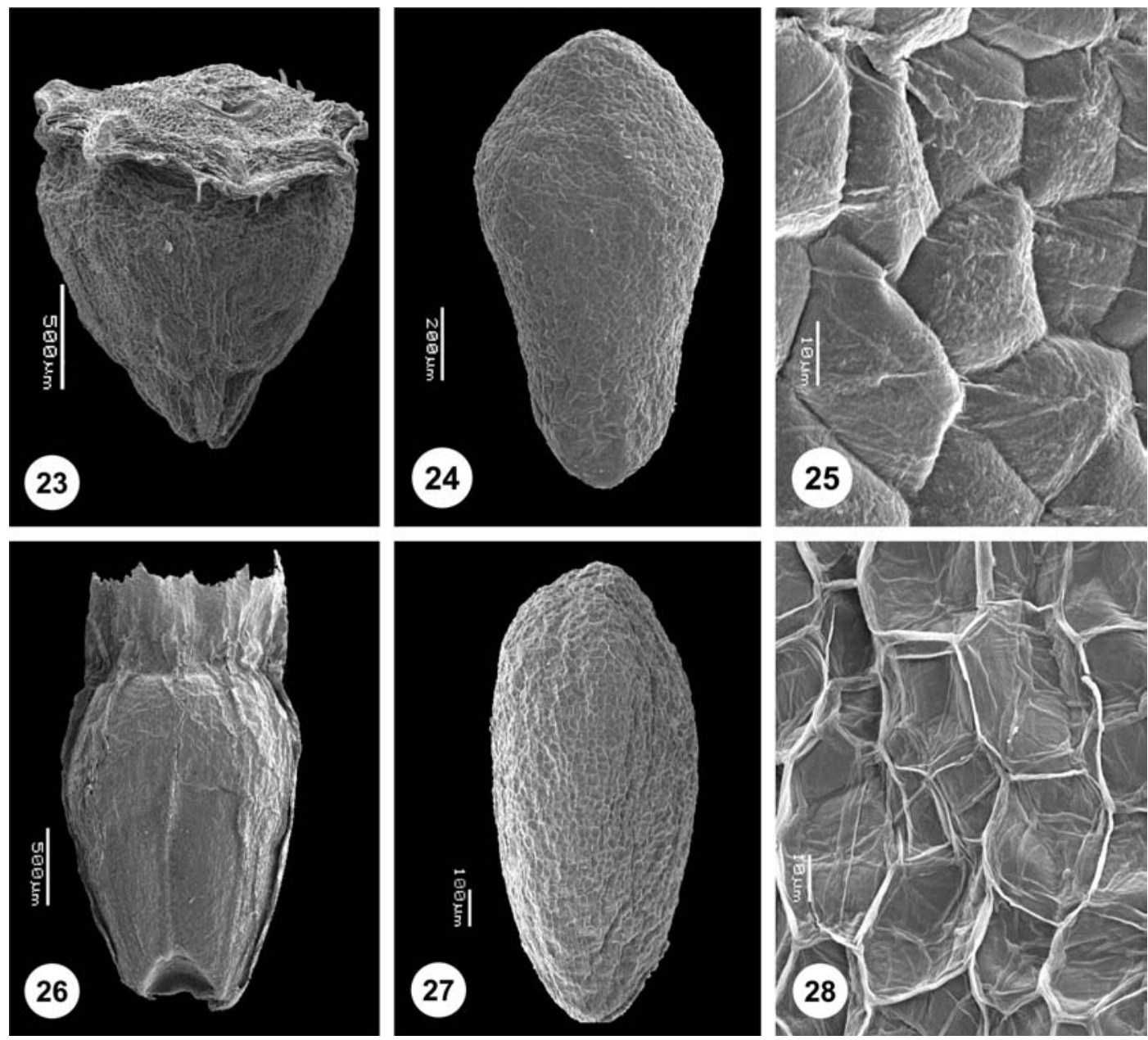

Figs. 23-28. Fruit and seed morphology of Gomphocalyx herniarioides (23-25) and Phylohydrax madagascariensis (2628). 23, lateral view of an almost mature fruit; 24 , dorsal view of seed; 25 , detail of seed coat surface; 26 , lateral view of mature fruit; 27 , dorsal view of seed; 28 , detail of seed coat surface. Figs. 23-25 from De Block \& al. 790, Madagascar (BR); Figs. 26-28 from Cours 2885, Madagascar (P).

between the two genera. The most obvious difference between Gomphocalyx and Phylohydrax lies in the growth form. Although the two species are essentially creeping herbs forming dense mats, Phylohydrax has a distinct differentiation into vegetative long creeping stems and short erect ones that bear the flowers. Gomphocalyx has no such shoot differentiation. Since growth forms are most likely to be influenced by parallel evolution, not too much attention should be paid to the dissimilarity, however. More important is the fact that fruit wall anatomy is different. In Phylohydrax a relatively thick sclerenchymatous endocarp is present, the mesocarp is relatively thin, the exocarp comprises only one cell layer with the vascular traces situated just underneath the exocarp. In Gomphocalyx, the fruit wall is superficially similar, but the mesocarp is more extensive, and the vascular traces lie close to the endocarp. Other differences are found in the nectary disc morphology (bilobed vs. entire), leaf anatomy (differentiated into spongy and palisade parenchyma vs. palisade parenchyma only), and calyx tube (reduced vs. collar-like calyx).

In conclusion, it is clear that morphology does not provide unambiguous evidence to call a close relationship between Gomphocalyx and Phylohydrax. On the other hand there are no characters that contradict such a relation. Indeed, for very specialized genera such as Gomphocalyx and Phylohydrax it is often difficult to determine close relatives based on morphology alone.

Gomphocalyx and Phylohydrax ruled out from Spermacoceae. - Molecular data are conclusive to exclude Gomphocalyx and Phylohydrax from Spermacoceae s.s., but is there also morphological evidence for this? To answer this question we will first evaluate the characters that were used to classify the two genera in the tribe Spermacoceae s.s., i.e., (1) the presence of pluri-zonocolporate pollen grains, and (2) an ovary with 


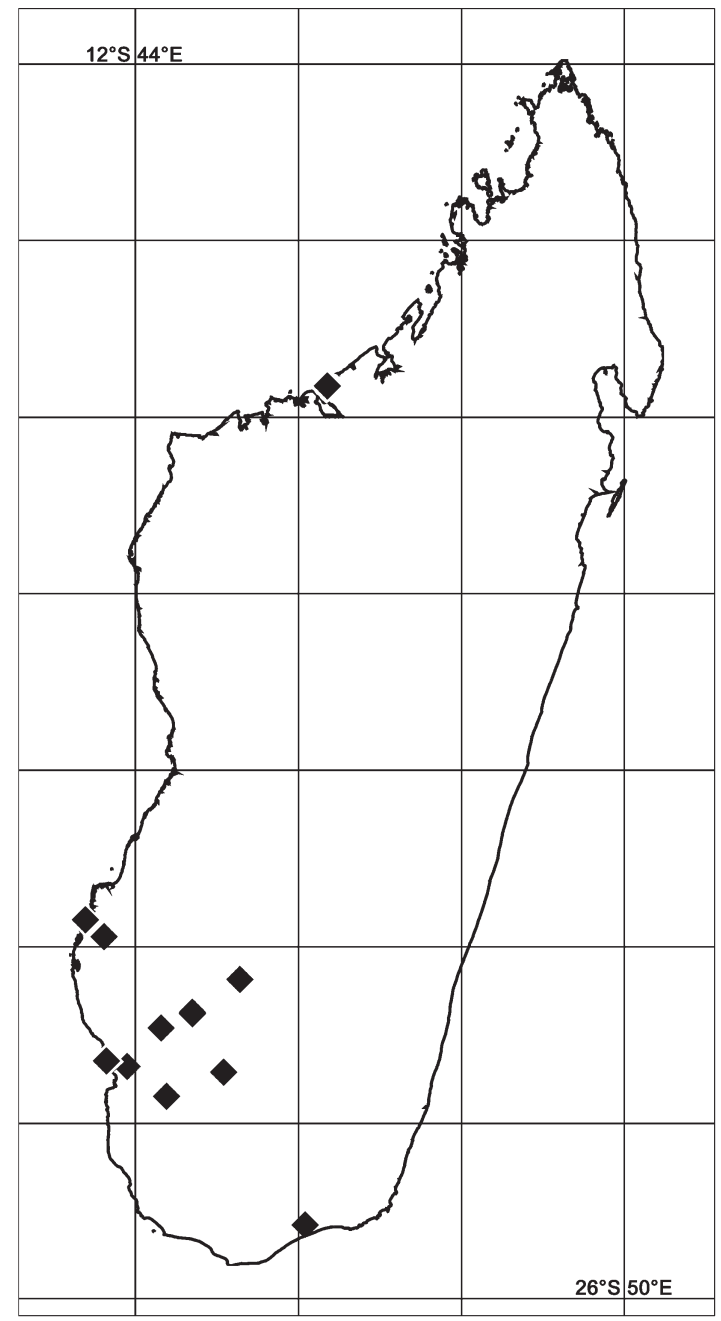

Fig. 29. Distribution of Gomphocalyx herniarioides.

only a single ovule per locule. A closer look at these characters will prove that the pollen argument is rather weak because of the presence of convergent evolution, and that the ovary features do not hold when more detailed gynoecial characters are taken into account.

One of the main characteristics of Spermacoceae s.s. is the presence of pluri-aperturate pollen. Indeed, almost all members of the clade have pollen grains with more than three colpi or pores, and those with three colpi have a very peculiar morphology with a margo of granules around the ectoapertures only observed in this clade (Dessein \& al., 2002). Pluri-aperturate pollen grains are not restricted to Spermacoceae s.s., however. The tribe Rubieae, for example, is characterized by 5-13-zonocolpate pollen and Theligoneae by 4-8-zonoporate pollen (Huysmans \& al., 2003). In other tribes, the pluri-aperturate pollen condition is not a tribal characteristic, but is observed in a few species or genera only. In Psychotrieae, for example, the number of apertures is variable but rarely more than 5. In Geophila repens (L.) I. M. Johnst., however, a genus belonging to the same tribe, up to 150 pores were counted (Piesschaert \& al., 1999; Vanthournout, 2002). In the Hedyotideae-Hedyotis group, several genera show a tendency to develop more than three apertures. In Neanotis W. H. Lewis, for example, pollen grains are very similar to what is observed in Gomphocalyx and Phylohydrax: pollen is (5-)6-12zonocolporate, the colpi are short, and the tectum is (micro-)reticulate (Lewis, 1966). Pluri-zonocolporate pollen is also found in Lathraeocarpa (Figs. 37-40), which is further discussed below. In short, pluri-aperturate pollen grains are not uncommon outside Spermacoceae s.s.

Uni-ovulate locules are found in numerous genera and tribes and originated several times in the evolution of Rubiaceae. In most members of the subfamily Rubioideae, the ovules are erect with an inferior micropyle and attached to the base or middle of the septum. In some tribes, formerly placed in the subfamily Antirheoideae (Robbrecht, 1988), the micropyle is superior and the ovules are pendulous. The former condition characterizes Spermacoceae s.s. The ovules are attached to the septum typically just below its middle (Richardia L. being the only known exception with the ovules attached near the base). This is not the case for Phylohydrax and Gomphocalyx, where the ovules are attached near the base of the septum, which is the most common condition in other uni-ovulate taxa (e.g., Paederieae, Psychotrieae). Hence, the attachment of the ovule near the base of the septum corroborates the exclusion of the two genera from Spermacoceae s.s.

Additional morphological support to reject a close relationship between Gomphocalyx-Phylohydrax and Spermacoceae s.s. is found in the absence of a ventral groove in the seeds of the former two genera. In Spermacoceae s.s., such a groove (often very deep and narrow, more rarely wide and shallow) is almost omnipresent (see also Terrell \& Wunderlin, 2002). Note that the seeds of Hydrophylax have a distinct ventral groove, and that they are attached near the middle of the septum (Puff, 1986). Any doubt about the position of Hydrophylax within Spermacoceae s.s. on the basis of these grounds is therefore not justified.

A position outside Spermacoceae s.s. is thus fairly well supported morphologically. But is there also support for the new position of the genera amidst taxa of Hedyotideae known as closely related to Oldenlandia? Before attempting to answer this question, it should be noted that the current molecular sampling of Hedyotideae is insufficient. In our opinion, a close relationship between the African genus Conostomium and Phylohydrax-Gomphocalyx, as suggested by our molecular data, is most unlikely and is the result of this poor 

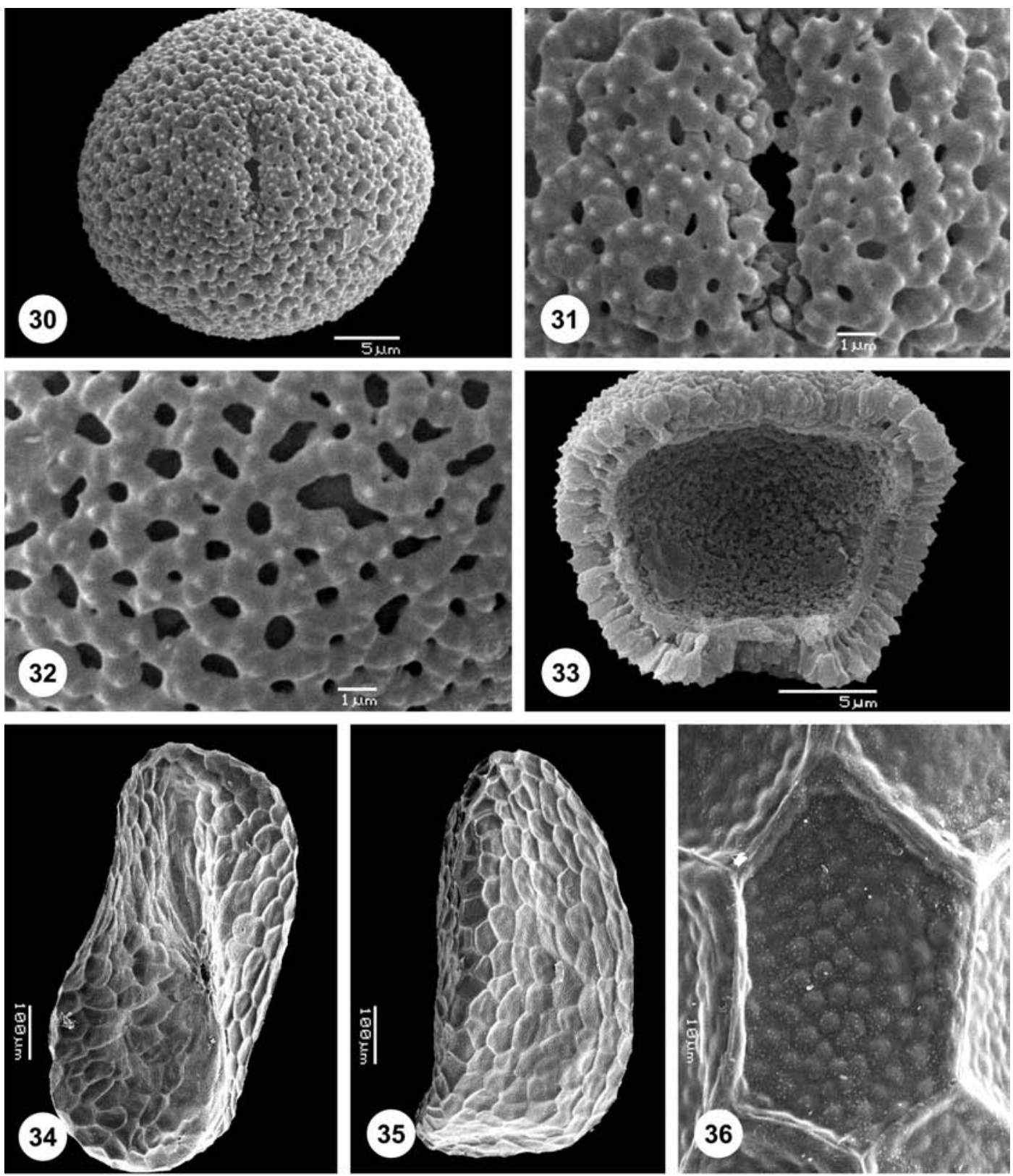

Figs. 30-36. Pollen and seed morphology of Conostomium. 30, equatorial view of 3-zonocolporate pollen grain; 31, detail of colpus; 32, detail of apocolpium showing microreticulate tectum with granules; 33 , view of inside of pollen grain showing granular nexine and layers of the pollen wall; 34 , ventral view of seed: note position of hilum; 35 , dorsal view of seed; 36, detail of seed coat surface. Figs. 30-33 from Chase 6039, Zimbabwe (BR). Figs. 34-36 from Brenan \& al. 1844, Kenya (BR).

sampling. Indeed, Conostomium is a small genus of herbaceous plants that is endemic to tropical Africa (see Bremekamp, 1952; Dessein, 1998; Scheltens, 1998). It is characterized by pluri-ovulate placentas, capsular fruits with a distinct beak, and 3-zonocolporate pollen grains with a perforate to microreticulate tectum (Figs. 30-33). The seeds are very small and the outer tangential wall of the seed coat cells is punctate (Figs. 34-36). There is not a single morphological character known by us that would support a close relationship between Conostomium and Phylohydrax-Gomphocalyx.

Whatever the relatives of Phylohydrax and Gomphocalyx are within Hedyotideae, two discontinuities in the series of morphological character states will have to be explained. The first one concerns the uni-ovulate condition of both Gomphocalyx and Phylohydrax, the second one the pluri-aperturate pollen grains. Indeed, almost all taxa of Hedyotideae have pluri-ovulate ovaries 

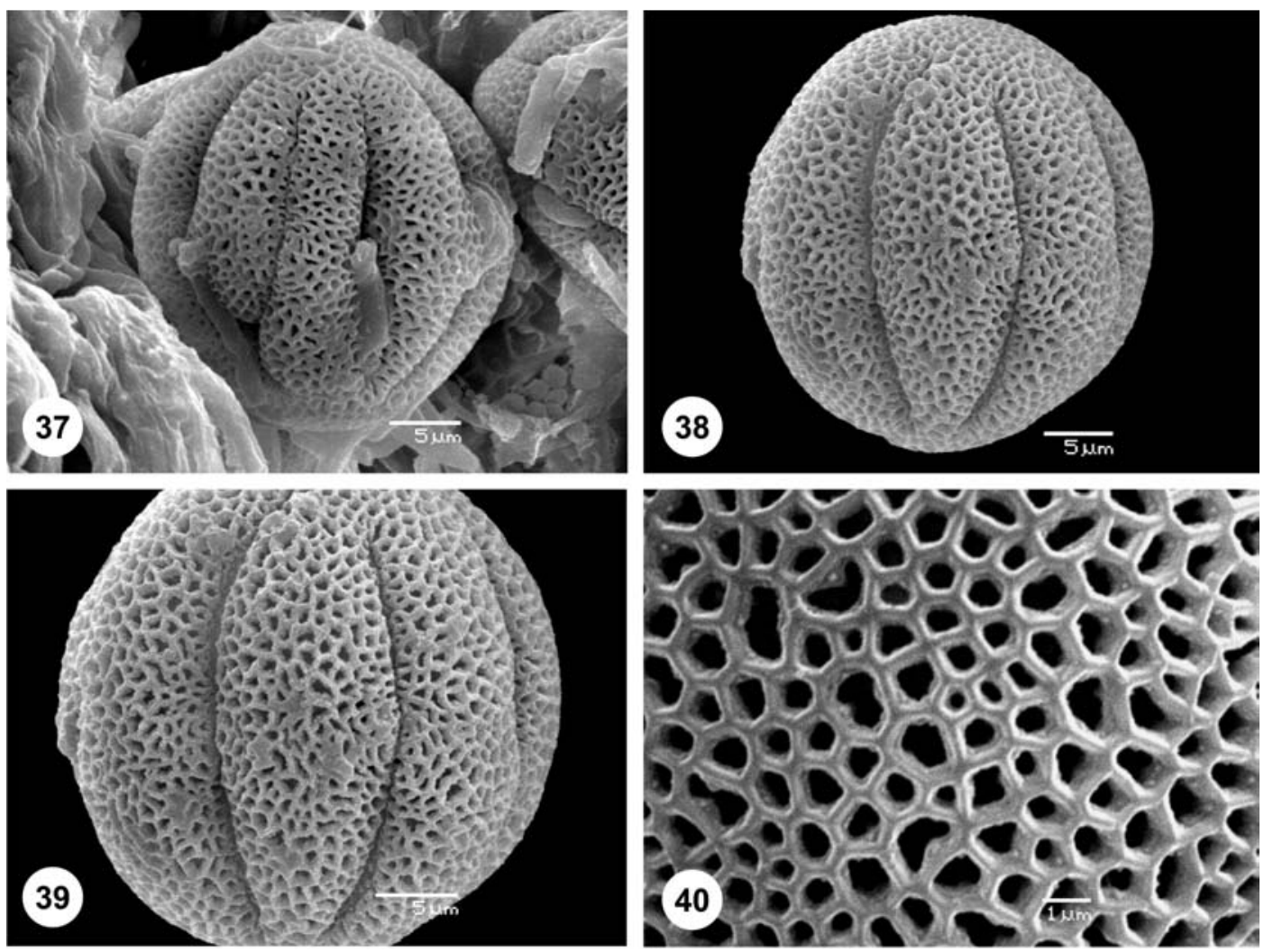

Figs. 37-40. Pollen morphology of Lathraeocarpa decaryi. 37, equatorial view of unacetolysed pollen grain; 38, equatorial view of pollen grain; 39, detail of equatorial zone; 40, detail of mesocolpium showing (micro-)reticulate tectum. All from Decary 9508, Madagascar (P).

and the number of apertures of the pollen grains rarely exceeds five. One exceptional taxon should be mentioned, however, namely the Asian genus Neanotis. As already mentioned above, Neanotis has pluri-zonocolporate pollen grains that are very similar to those of Gomphocalyx and Phylohydrax. What is more interesting, however, is that this genus also shows a clear reduction trend in the number of seeds per locule. In mature fruits, only one or two seeds are present and the fruits often remain indehiscent. In the absence of sequence data, it would be premature to hypothesize a close relationship between Phylohydrax-Gomphocalyx and Neanotis, but Neanotis shows at least that the evolutionary tendency to develop pluri-aperturate pollen grains and uni-ovulate ovaries is present in Hedyotideae. This makes more plausible the hypothesis that Phylohydrax and Gomphocalyx developed directly from a Hedyotideae ancestor and that character states similar to representatives of Spermacoceae s.s. were obtained via convergent evolution.

Remarkable convergent evolution. - The above observations bring up new questions about the ecological and functional significance of morphological changes. The similar growth form observed in Phylo- hydrax and Hydrophylax is easily explained by similar growth conditions. In fact, several other pioneers of maritime dune vegetation show parallel adaptations. Within Rubiaceae, "Diodia" vaginalis Benth. (Spermacoceae s.s.; the position of this species in Diodia is doubtful; Dessein, 2003) from West-Africa also has a similar habit, while fruit and pollen morphology indicate that it is not closely related to Hydrophylax or GomphocalyxPhylohydrax.

More intriguing is the observation that in several evolutionary lineages of Rubiaceae a reduction in the number of seeds and an augmentation of the number of apertures in the pollen grains is present, and that those character states are often correlated. More fine-tuned phylogenies and detailed ecological studies that estimate the fitness of species in their environment may help reveal the triggers of such apparently related morphological tendencies.

Another strange Madagascan genus: Lathraeocarpa. - As mentioned in the introduction, a few authors have proposed a close relationship between Lathraeocarpa and Gomphocalyx, and Piesschaert (2001) even proposed merging the two genera. Lathraeocarpa comprises two subshrubby species, which are 
endemic to the southernmost part of Madagascar. It is another deviant genus, mainly characterized by ternate leaves, truncate stipules (with one or a few teeth) fused with the petioles, calyx lobes in number twice the number of corolla lobes, heterostyly, tetralocular gynoecia with one basal ovule per locule, drupaceous fruits, and pluri-zonocolporate pollen grains (Figs. 37-40). In the protologue of Lathraeocarpa, Bremekamp (1957) dismissed any affinity between the novelty and Spermacoceae s.s., because (1) the ovules are attached around the middle of the septum in Spermacoceae (and not at the base), (2) the fruits are capsules or dicoccous fruits (and not drupes), and (3) the pollen grains of Spermacoceae lack pores. The first statement is here confirmed. Now that Gomphocalyx and Phylohydrax are excluded from Spermacoceae s.s., all genera left in the clade, except for Richardia, have their ovules attached around the middle of the septum. Bremekamp's other two criteria are more problematic. In fact, several genera of Spermacoceae s.s. do have indehiscent fruits that tend to be fleshy (e.g., the neotropical genera Ernodea and Tortuella Urb.), and the combination of colpi and pores is, e.g., found in Scandentia E. L. Cabral \& Bacigalupo, another neotropical genus. There is, however, another character that makes a real affinity between Lathraeocarpa and Spermacoceae s.s. doubtful, viz., the absence of a ventral groove in the developing Lathraeocarpa seeds.

A position near Gomphocalyx seems at first sight more convincing. The two genera have a similar stipule, calyx, and pollen morphology (pollen of Lathraeocarpa is 7-8-zonocolporate with E $41-50 \mu \mathrm{m}$ ). Some differences, however, obscure the picture and some characters point to an affinity between Lathraeocarpa and Triainolepis Hook. f., an Afro-Madagascan member of emended Knoxieae. The main reason for questioning a relationship between Gomphocalyx and Lathraeocarpa is that the ovary of the latter genus is tetralocular. Furthermore, the fruits of Lathraeocarpa are fleshy and not dry as in Gomphocalyx, and in Lathraeocarpa decaryi Bremek., the pyrene is surrounded by eight strands of thin-walled cells, very similar to the fruit wall anatomy observed in some Triainolepis species (see Bremekamp, 1957; Piesschaert, 2001). The subshrubby habit of Lathraeocarpa is also much closer to the shrubby habit of Triainolepis than to the herbaceous habit of Gomphocalyx. The fusion of Lathraeocarpa and Gomphocalyx as proposed by Piesschaert (2001) is not corroborated by our current knowledge. Once more, we will have to wait until molecular data become available to determine the position of Lathraeocarpa more confidently.

\section{ACKNOWLEDGEMENTS}

We would like to thank Anja Vandeperre for the botanical drawings and Marcel Verhaegen for making SEM-photographs. We are also grateful to the keepers of the herbaria for providing herbarium material. A visit to the herbarium of Paris was supported through the Colparsyst programme. Piero Delprete and an anonymous reviewer are thanked for their contribution to this final version. Steven Dessein is a postdoctoral fellow of the Fund for Scientific Research (F. W. O.) Flanders. This study was supported by a grant from the Research Council of the K. U. Leuven (OT/01/25) and by a grant from the F. W. O. (G.0104.01).

\section{LITERATURE CITED}

Andersson, L. \& Rova, J. H. E. 1999. The rps16 intron and the phylogeny of the Rubioideae (Rubiaceae). Pl. Syst. Evol. 214: 161-186.

Baker, J. H. 1887. Flora of Madagascar. Gomphocalyx, genus novum Rubiacearum tribus Spermacoceae. J. Linn. Soc., Bot. 22: 485-486.

Bremekamp, C. E. B. 1952. The African species of Oldenlandia L. sensu Hiern et K. Schumann. Verh. Kon. Ned. Akad. Wetensch., Afd. Natuurk., Tweede Sect., 48: 1-297.

Bremekamp, C. E. B. 1957. Les Lathraeocarpées, tribu nouvelle des Rubioidées (Rubiacées). Bull. Jard. Bot. État. 27: 159-166.

Bremer, B. 1996. Phylogenetic studies within Rubiaceae and relationships to other families based on molecular data. In: Robbrecht, E., Puff, C. \& Smets, E. (eds.), Second International Rubiaceae Conference Proceedings, Meise 1995. Opera Bot. Belg. 7: 33-50.

Bremer, B. \& Manen, J. F. 2000. Phylogeny and classification of the subfamily Rubioideae (Rubiaceae). Pl. Syst. Evol. 225: 43-72.

Capuron, R. 1973. Révision des Rubiacées de Madagascar et des Comores. Unpublished manuscript. Notes regroupées et mises en forme par J. Bosser, dactylographiées de F. Chauvet. Laboratoire de Phanérogamie, Paris.

Chase, M. W. \& Hills, H. H. 1991. Silica gel: an ideal material for field preservation of leaf samples for DNA studies. Taxon 40: 215-220.

De Vogel, E. F. 1987. Manual of Herbarium Taxonomy: Theory and Practice. Unesco, Regional Office for Science and Technology, Indonesia.

Dessein, S. 1998. Fylogenie van de Hedyotideae (Rubiaceae). Een morfologische en anatomische studie van de Afrikaanse taxa. Licentiate thesis, Katholieke Universiteit Leuven, Leuven.

Dessein, S. 2003. Systematic Studies in the Spermacoceae (Rubiaceae). Ph.D. thesis, Katholieke Universiteit Leuven, Leuven.

Dessein, S., Andersson, L., Robbrecht, E. \& Smets, E. 2001. Hekistocarpa (Rubiaceae): a member of an emended tribe Virectarieae. Pl. Syst. Evol. 229: 59-78.

Dessein, S., Huysmans, S., Robbrecht, E. \& Smets, E. 2002. Pollen of African Spermacoce species (Rubiaceae): mor- 
phology and evolutionary aspects. Grana 41: 69-89.

Dessein, S., Scheltens, A., Huysmans, S., Robbrecht, E. \& Smets, E. 2000. Pollen morpholoigcal survey of Pentas (Rubiaceae-Rubioideae) and its closest allies. Rev. Palaeobot. Palynol. 112: 189-205.

Geuten, K., Smets, E., Schols, P., Yuan, Y.-M., Janssens, S., Küpher, P. \& Pyck, N. 2004. Conflicting phylogenies of balsaminoid families and the polytomy in Ericales: combining data in a Bayesian framework. Molec. Phylog. Evol. 31: 711-729.

Holm, T. 1907. Rubiaceae: Anatomical studies of North American representative of Cephalanthus, Oldenlandia, Houstonia, Mitchella, Diodia and Galium. Bot. Gaz. 43: $153-184$.

Huysmans, S., Dessein, S., Smets, E. \& Robbrecht, E. 2003. Pollen morphology of NW European representatives confirms monophyly of Rubieae (Rubiaceae). Rev. Palaeobot. Palynol. 127: 219-240

Lewis, W. H. 1966. The Asian genus Neanotis nomen novum (Anotis) and allied taxa in the Americas (Rubiaceae). Ann. Missouri Bot. Gard. 53: 32-46.

Oxelman, B., Liden, M. \& Berglund, D. 1997. Chloroplast rps16 intron phylogeny of the tribe Sileneae (Caryophyllaceae). Pl. Syst. Evol. 206: 393-410.

Piesschaert, F. 2001. Carpology and Pollen Morphology of the Psychotrieae (Rubiaceae-Rubioideae). Towards a New Tribal and Generic Delimitation. Ph. D. thesis, Katholieke Universiteit Leuven, Leuven.

Piesschaert, F., Robbrecht, E., Poulsen, A. D. \& Smets, E. 1999. Pyrene and pollen observations in the pantropical genus Geophila (Rubiaceae-Psychotrieae). Nordic J. Bot. 19: 93-100.

Puff, C. 1986. Phylohydrax (Rubiaceae-Spermacoceae) - a new genus to accommodate the African and Madagascan "Hydrophylax" species. Pl. Syst. Evol. 154: 343-366.

Reitsma, T. 1969. Size modifications of recent pollen grains under different treatments. Rev. Palaeobot. Palynol. 9: 175-202.

Robbrecht, E. 1988. Tropical woody Rubiaceae. Characteristic features and progressions. Contributions to a new subfamilial classification. Opera Bot. Belg. 1: 1-272.

Scheltens, A. 1998. Pollenmorfologische studie van de Afrik- aanse Hedyotideae (Rubiaceae). Licentiate thesis, Katholieke Universiteit Leuven, Leuven.

Schols, P., Dessein, S. \& Smets, E. 2001. How to use iMap version 2.0. Distributed by the authors (http://www .kuleuven.ac.be/bio/sys/imap).

Schumann, K. 1891. Rubiaceae. Pp. 1-156 in: Engler, A. \& Prantl, K. (eds.), Die natürlichen Pflanzenfamilien, vol. 4, part 4. Engelmann, Leipzig.

Swofford, D. L. 2002. PAUP*. Phylogenetic Analysis Using Parsimony (*and Other Methods), Version 4. Sinauer Associates, Sunderland, Massachusetts.

Terrell, E. E. \& Wunderlin, R. P. 2002.. Seed and fruit characters in selected Spermacoceae and comparison with Hedyotideae (Rubiaceae). Sida. Contrib. Bot. 20: 549-557.

Vanthournout, S. 2002. Geophila. Revisie van de paleotropische taxa. Licentiate thesis, Katholieke Universiteit Leuven, Leuven.

Verdcourt, B. 1976. Rubiaceae (Part 1). Tribe 8. Hedyotideae. Pp. 177-315 in: Polhill, R. M. (ed.), Flora of Tropical East Africa. Crown Agents for Oversea Governments and Administrations, London.

\section{Appendix 1. Specimens studied of Gomphocalyx herniarioides.}

Madagascar. Fian: Route Nat. 7, Isalo-Sakaraha, forêt de Zombitse, L. Allorge 2097 (P); Plateaux et vallées de l'Isalo à l'ouest de Ranohira, H. Humbert 28740 (P), 28703 (P), 19581 (P). Maha: Majunga, $3 \mathrm{~km} \mathrm{~N}$ of the city, on the beach, P. De Block \& al. 790 (BR); Belamonty forest, Fok. d'Antsanitia, 2 km from coast, P. De Block \& F. Rakotonasolo 812 (BR); Majunga (Pointe du Caïman); H. Humbert 7171 (P); Environs de Majunga, H. Humbert 4076 (P); Sables des dunes de Majunga au soleil, H. Perrier de la Bâthie 3503 (P); Majunga, H. Poisson 46 (P). Toli: Anakao vers Beheloka, L. Allorge 2276 (P); environs de Tuléar, M. J. Bosser 10409 (P); Sakaraha, M. J. Bosser 9135 (P); on RN 7 from Toliara towards "La Table", ca. 10 km from Toliara, P. De Block \& al. 569A \& B (BR); Morombé, R. Decary 18743 (P); Ambovombe, R. Decary 3489 (P); Ferme de Mahabo, J. Dequaire 27096 (P); Bas Mangoky, Descoings 784 (P); Côte ouest de Madagascar, De Manombo à Morondava, Grandidier s.n. (P); Forêt de Zombitsy (Sakaraha); aux confins des bassins du Fiherenana et de l'Onil, H. Humbert \& al. 29667 (P); environs de Tuléar: delta du Fiherenana, H. Humbert \& H. Perrier de la Bâthie 2453 (P); environs de Sakaraha, forêt du Zombitsy, M.-R. Keraudren 492 (P); N of Tuléar, Lac Ihotry, P.B. Phillipson 3049 (MO, P); Bassin de Fiherenana, H. Perrier de la Bâthie 3893 (P); Vallée du Fiherenana, H. Perrier de la Bâthie 16673 (P); Tuléar, H. Perrier de la Bâthie 12831 (P); Benenitra, H. Perrier de la Bâthie 12741 (P); "La Table", Tuléar, M. Petit 23 (P); Route de Betioky à Sakamena, H. Poisson 427, $436(\mathrm{P})$; Beza Mahafaly special reserve, NE of Betioky, parcell 2, "pink trail”, T. Willing 61 (P). Without locality or locality not traced: R. Baron 4585 (P00267333), 4782 (P00267332); M. R. Decary 18741 (P); M. Grevé 63, 304, 331 (P); A.-M. Homolle 1567 (P); C. Rutenberg s.n. (P00267331). 


\section{Appendix 2. Vouchers for sequences used in the cladistic analyses with GenBank accessions.}

\section{Taxon, Voucher data, rbcL, rps16 intron}

Agathisanthemum Klotzsch: A. bojeri Klotzsch, South Africa, Transvaal, Dahlstrand 1625 (GB), AF002752; Tanzania: Bremer 3060 (UPS), Z68787. Amphiasma Bremek.: A. benguellense (Hiern) Bremek., Angola, Moçamedes district: Kers 3350 (S), AF002753; A. luzuloides (K. Schum.) Bremek., Tanzania: Iversen \& al. 87694 (UPS), AJ288594. Anthospermum L.: A. aethiopicum L., South Africa: Dahlstrand 416 (GB), AF257897; A. herbaceum L. f., Tanzania: Bremer 3093 (UPS), X83623. Arcytophyllum Willd. ex Schult \& Schult. f.: A. aristatum Standl., Ecuador: Hekker \& Hekking 10335 (GB), AF333348; Ecuador: Bremer \& al. 3371 (UPS), AJ288595; A. muticum (Wedd.) Standl., Colombia, Cundinamarca: Andersson \& al. 2195 (GB), AF002754; A. riveti Danguy \& Cherm., Ecuador: Harling \& Andersson 22232 (GB), AF333362; A. serpyllaceum (Schltdl.) Terrell, Mexico: Stafford \& al. 203 (MO), AF333364; A. thymifolium (Ruiz \& Pav.) Standl., Ecuador: Ståhl 4481 (GB), AF333366. Argostemma Wall.: A. hookeri King, Malaysia: Wanntorp s.n. (S), Z68788; A. rupestre Ridl., Sarawak: Bremer \& Bremer 1675 (S), AF002756. Bouvardia Salisb.: B. glaberrima Engelm., Cultivated: Forbes s.n. (S), X83626; B. ternifolia (Cav.) Schltdl., Cultivated: S2928 (BR), AF002758. Conostomium (Stapf) Cufod.: C. natalense (Hochst.) Bremek., South Africa, Transvaal: Dahlstrand 1346 (GB), AF002760; C. quadrangulare (Rendle) Cufod., Ethiopia: Puff \& Kelbessa 821222 (UPS), Z68792. Coprosma J. R. Forst \& G. Forst.: C. pumila Hook. f., Cultivated: Forbes s.n. (S), X87146; C. robusta Raoul, Cultivated: Andersson 2206 (GB), AF002735. Craterispermum Benth.: C. laurinum (Poir.) Benth., R.D.Congo: Lejoly 86/207 (BR), AF331646, AF331645. Danais Comm. ex Vent.: D. xanthorrhoea (K. Schum.) Bremek., Tanzania: Bremer 3079 (UPS), Z68794; D. sp., Madagascar: Davis 1003 (K), AF331648. Dentella J. R. Forst \& G. Forst.: D. repens (L.) J. R. Forst. \& G. Forst., Australia: Andersson 2262 (GB), AF333370. Dibrachionostylus Bremek.: D. kaessneri (S. Moore) Bremek., Kenya, Nairobi: Strid 2598 (GB), AF002761. Didymaea Hook. f.: D. alsinoides (Cham. \& Schltdl.) Standl., Cultivated: Keller 1901 (CAS), Z68795. D. mexicana Hook. f., Mexico, México: Hultén 1259 (S), AF004047. Diodia L.: D. sarmentosa Sw., French Guiana: Anderson \& al. 2071 (GB), AF002762; Puerto Rico: Taylor 11749 (MO), AJ288600; D. virginiana L., USA: Vincent 4296 (GB), AY764288. Emmeorhiza Pohl ex Endl.: E. umbellata (Spreng.) K. Schum., Trinidad: Hummel s.n. (GB), AY764289. Ernodea Sw.: E. littoralis Sw., Cuba, National Botanical Garden: Rova \& al. 2286 (GB), AF002763; Cuba: Kiehn s.n. (WU), AJ288601. Galianthe Griseb.: G. brasiliensis (Spreng.) E. L. Cabral \& Bacigalupo, Argentina: Vanni \& Radovancick 996 (GB), AY764290. Gomphocalyx Baker: G. herniarioides Baker, Madagascar: De Block \& al. 569 (BR), AY764291. Hedyotis L.: H. degeneri Fosberg, Cultivated: Wood 5062 (PTGB), AF333371; H. hillebrandii (Fosberg) W. L. Wagner \& D. R. Herbst, Hawaii: Harrison-Gagne s.n. (GB), AF002765; H. macrostegia Stapf, Sabah: Wallander 6 (GB), AF002767; H. mitrasacmoides F. Muell., Australia: Andersson 2260 (GB), AF333372; H. parvula (A. Gray) Fosberg, Cultivated: Perlman 12783 (GB), AF333375; H. schlechtendahliana Steud., Cultivated: Lorence 8021 (PTBG), AF333376. Houstonia L.: H. caerulea L., USA: Vincent \& Lammers s.n. (GB), AF333379; cultivated, AJ288604; H. longifolia Gaertn., USA: Yatskievych 96-49 (MO), AF002766; H. microphylla Willd., Ecuador: Molau \& al. 2665 (GB), AF333377; H. nigricans (Lam.) Fernald, USA: Yatskievych 96-92 (MO), AF333373. Knoxia L.: K. platycarpa Arn., Sri Lanka: Lundqvist 11302 (UPS), AJ288631; K. sumatrensis (Retz.) DC. , India, Bihar: Dahlstrand s.n. (GB), AF002738. Manettia Mutis ex L.: M. alba (Aubl.) Wernh., French Guiana: Andersson \& al. 1917 (GB), AF002768; M. luteorubra (Vell.) Benth., Cultivated: Bremer 2716 (UPS), Z68803; M. lygistum (L.) Sw., Colombia, Cauca: Andersson \& al. 2128 (GB), AF002769. Mitracarpus Zucc. ex Schult. \& Schult. f.: M. frigidus (Willd. ex Roem. \& Schult.) K. Schum., French Guiana: Andersson \& al. 1995 (GB), AF002770; M. villosus (Sw.) Cham. \& Schltdl., Sri Lanka: Fagerlind 810 (S), AJ288632. Morinda L.: M. citrifolia L., Cultivated: Bremer 3106 (UPS), X83651; Cultivated at Dept. of Botany, Stockholm University, acc. ${ }^{\circ}$ SU-C-88.38: no voucher, AF001442. Mycetia Reinw.: M. malayana (G. Don) Craib, Cultivated: Andersson 2219 (GB), AF002771; Cultivated: Larsen \& al. 42486 (AAU, UPS), Z68806. Nesohedyotis (Hook. f.) Bremek.: N. arborea (Roxb.) Bremek., Cultivated: Chase 2915 (K), AF003607. Oldenlandia L.: O. affinis (Roem. \& Schult.) DC., South Africa, Transvaal: Dahlstrand 1661 (GB), AF003608; O. corymbosa L., Gabon: Andersson \& Nilsson 2263 (GB), AF333381; Tanzania: Bremer 3075 (UPS), X83655; O. lancifolia (Schumach.) DC., French Guiana: Andersson \& al. 1996 (GB), AF003609; O. nervosa Hiern, Gabon: Andersson \& Nilsson 2326 (GB), AF333382; O. tenuis K. Schum., Guyana: Jansen-Jacobs \& al. 41 (U), AY764293; O. thesiifolia (A.St.-Hil.) K. Schum., Brazil: Harley 15514 (U), AY764294; O. uniflora L., USA: Godfrey 57268 (GB), AY764295. Opercularia Gaertn.: O. vaginata Juss., Australia: Nordenstam \& Anderberg 627 (S), AF257936; Australia: Bremer \& Gustafsson 25 (UPS), Z68809. Otiophora Zucc.: O. cupheoides N. E. Br., South Africa, Transvaal: Hilliard \& Burtt 14307 (S), AF002742; South Africa: Bremer 3805 (UPS), AJ288613. Otomeria Benth.: O. oculata S. Moore, Kenya, Samburu district: Newbould 29015 (S), AF002743; Ethiopia: Puff 821222-2/1 (K), AJ288614. Paederia L.: P. foetida L., Cultivated: Without voucher (acc. No. 19763869), AF004065; Japan: Ehrendorfer 930830-0801, AF332373. Pagamea Aubl.: P. guianensis Aubl., French Guiana: Andersson \& al. 2015 (GB), AF002744. Pentanisia Harv.: P. longituba (Franch.) Oliv., Ethiopia: Puff \& Kelbessa 821220 (UPS), Z68812; P. prunelloides (Eck1. \& Zeyh.), South Africa, Eastern Cape: Dahlstrand 1972 (GB), AF002745. Pentas Benth.: P. lanceolata (Forssk.) Defl., Cultivated: Andersson 2248 (GB), AF002750; Cultivated: Bremer 2702 (S), X83659. Pentodon Hochst.: P. pentandrus (K. Schum. \& Thonn.) Vatke, Zanzibar: Sundström 2 (GB), AF003612; Tanzania: Bremer 3082 (UPS), X83660. Phylohydrax Puff: P. carnosa (Hochst.) Puff, South Africa: Bremer 3783 (UPS), AJ288615; P. madagascariensis (Willd. ex Roem. \& Schult.) Puff, Madagascar: De Block \& al. 640 (BR), AY764292. Plocama Aiton: P. pendula Aiton, Cultivated: Bremer 3321 (UPS), AF004071; Canary Islands: Andreasen 1 (UPS), Z68816. Psychotria L.: P. asiatica L., Cultivated at Royal Botanic Garden, Edinburgh: without voucher (accession number 19780778A), AF369854. Psyllocarpus Mart. \& Zucc.: P. asparagoides Mart. \& Zucc., Brazil, Bahia: Harley \& al. 20077 (AAU), AF003611; P. laricoides Mart. \& Zucc., Brazil: Andersson \& al. 355750 (UPS), AJ288619. Putoria Pers.: P. calabrica (L. f.) DC., Cultivated at Royal Botanic Gardens, Kew: without voucher, AF004072; Unknown: Jonsell 4216 (UPS), AJ288620. Richardia L.: R. scabra L., Colombia: Andersson \& al. 2073 (GB), AF003614; Cultivated: Bremer 2744 (UPS), Z68820. Rubia L.: R. fruticosa Aiton, Cultivated: Andersson 2224 (GB), AF004078; R. tinctorum L., Cultivated: Bremer 3300 (UPS), X83666. Schismatoclada Baker: S. sp., Madagascar: Antananarivo province: Philipson1608 (S), AF003618. Schradera Vahl: S. sp., Colombia: Cauca: Andersson \& al. 2107, AF003617; S. subandina K. Krause, Ecuador: Clark \& Watt 783 (UPS), Y11859. Serissa Comm. ex A. Juss.: S. japonica (Thunb.) Thunb., Cultivated: Andersson 2202 (GB), AF004081; Cultivated: Bremer 2717 (UPS), Z68822. Spermacoce L.: S. confusa Rendle ex Gillis, Colombia: Andersson \& al. 2074 (GB), AF003619; S. hispida L., Sri Lanka: Wanntorp \& al. 2667 (S), AJ288623. Theligonum L.: T. cynocrambe L., Spain, Málaga: Dept. of Systematic Botany 1298 (GB), AF004087; Cultivated: Struwe 1004 (UPS), X83668. Triainolepis Hook. f.: T. africana Hook. f., Kenya: Lorence 5553 (PTBG), AF129276; T. hildebrandtii Vatke, Kenya: Bally 13258 (G), AJ288625. 